\title{
TRADE LIBERALIZATION, EMPLOYMENT AND POVERTY
}

\section{Frank Ellis*}

The following papers present two alternative views of an ongoing project in the Institute concerned with the potential for export expansion to act as a source of employment generation and poverty alleviation in the developing countries. The papers are written by Hans Singer who has directed our interests in this area over the last two years, and Percy Selwyn who was involved in helping to prepare a preliminary version of the study while spending a period at IDS as a home-based Fellow.

The two writers broadly agree that trade liberalization which focuses attention on enabling developing countries to expand their exports of products which will have high gains in terms of employment and reduction of poverty is a most desirable objective of future trade negotiations between rich and poor countries. They would also agree (a) that the direct employment in the export industry taken on its own may only be a comparatively minor part of the total employment and distributional implications of a given increase in exports; and that therefore employment generated through intersectoral linkages and through the multiplier potential of increased foreign exchange availability must also be taken into account when examining different commodities; (b) that these latter indirect effects will be strongly influenced by the institutional and structural conditions under which exports are produced. A realistic assessment must therefore include factors such as whether the commodity is produced and traded by a multinational company; whether its production takes place in an 'enclave' type situation; and whether government policies are directed towards ensuring that widespread gains from the activity occur.

Where the writers do not reach a consensus is on the policy stance which should be adopted by rich countries in seeking to ensure that the outcome of trade negotiations will work for the maximum achievement of poverty-oriented objectives. Hans Singer argues that

\footnotetext{
*Frank Ellis is a Research Officer at the Institute of Development Studies.
} 
to the extent that the policies and attitudes of poor countries' own governments largely determine whether the benefits of export expansion reach poor people or generate widespread employment, there is a strong case for some degree of selectivity between countries in determining in what directions trade should be liberalized. Under this scenario rich countries are urged to seek in trade negotiations conditions which ensure that the maximum export expansion potential is directed towards those countries whose governments were most likely to take advantage of concessions from a poverty-oriented viewpoint. Of course, such selectivity need not be operated directly by favouring some countries above other countries, but could be achieved indirectly through the choice of products it was decided to liberalize (or in the case of balanced bilateral trade expansion through the pattern of exchange of products decided upon). Percy Selwyn points to the potential dangers which might accompany such a shift in conception of trade negotiations. He argues that a movement in the direction of 'country selectivity' in trade (even if most carefully hedged about with conditions and constraints) would fall foul of precisely the same ambiguities which are at present associated with the criteria used by rich countries in determining their aid commitments: both rich and poor country governments can change (such changes implying a continual and impossibly complicated re-alignment of preferential configurations); and there could be no guarantee that rich country governments would not use such a system for political or self-interest purposes.

This debate on whether 'country selectivity' in trade is a viable policy concept should not be taken as detracting from the validity of the central theme of the work, about which both writers would be in accord. The necessity of taking into account institutional and structural factors (including the role of government) when evaluating the performance of a developing country's export sector is not in doubt. 